\title{
'Every drop of my blood sings our song. There, can you hear it?': Haptic sound and embodied memory in the films of Apichatpong Weerasethakul
}

\section{ABSTRACT}

Frequently drawing on avant-garde formal strategies, bringing together personal, social and cultural memories in a cinematic collage, the films of Thai director Apichatpong Weerasethakul recreate what Richard Dyer has called 'the texture of memory' (Dyer 2010). Using narrative techniques such as repetition, fragmentation, and convergence (as different threads of a narrative resonate uncannily both within and across the films), the work expresses what the process of remembering feels like, how the warp and weft of the past continuously moves through and shapes the present just as the present shapes our memories of the past. While sound design in classical cinema often privileges the voice, lowering ambient sound in order to ensure intelligibility while creating an illusion of naturalism, in these films 'natural' ambient or environmental sounds are amplified to the extent that they become almost denaturalized, thus

\section{KEYWORDS}

sound haptic phenomenology affect memory Thai cinema Apichatpong Weerasethakul spectatorship embodiment

The New Soundtrack 3.1 (2013): 61-79

DOI: 10.3366/sound.2013.0036

(C) Edinburgh University Press www.euppublishing.com/SOUND 
heightening their affective power. In Blissfully Yours (Sud sanaeha, 2002), Tropical Malady (Sud pralad, 2004), Syndromes and a Century (Sang sattawat, 2006) and Uncle Boonmee Who Can Recall His Past Lives (Loong Boonmee raleuk chaat, 2010) the sound of the environment is often so dominant that it dismantles our reliance on the verbal or the linguistic to ground our understanding of what is happening in the narrative, and instead encourages (or rather insists upon) an embodied, phenomenological, engagement with the sensuality of the scene. This use of sound and textual synaesthesia foregrounds sound's materialism and its relationship to touch, sight, and taste, creating a feeling of sensory immersion on the part of the spectator where the senses seem to become indistinct. Alongside frequent bursts of pop music (expressing jouissance), the films' sound designer Akritchalerm Kalayanamitr uses these environmental sounds to create rhythmic 'sonic sequences' that have themselves an almost musical quality reminiscent of experimental avant-garde compositions from the 1950s and 60s made up of single or multi-tracked field recordings. This essay examines these moments in Apichatpong's films and argues that they enable a sense of connection and intersubjectivity by appealing directly to the audio-viewer's shared knowledge of how we remember.

While sound design in classical cinema often privileges the voice, lowering ambient sound in order to ensure intelligibility, creating an illusion of naturalism, in the work of Thai artist and filmmaker Apichatpong Weerasethakul, 'natural' ambient or environmental sounds are amplified to the extent that they become almost denaturalized, thus heightening their affective power. In the feature films Blissfully Yours (Sud sanaeha, 2002), Tropical Malady (Sud pralad, 2004), Syndromes and a Century (Sang sattawat, 2006), Uncle Boonmee Who Can Recall His Past Lives (Loong Boonmee raleuk chaat, 2010), and the short films Mobile Men (2008), Ashes (2012b) and Cactus River (Khong Lang Nam, 2012), the sound of the environment is often so dominant that it dismantles our reliance on the verbal or the linguistic to ground our understanding of what is happening in the narrative, and instead encourages (or rather insists upon) an embodied, phenomenological, engagement with the scene. Recognising the permeability of the imaginary line between the spectator's body and the 'body' of the film forms the basis of important recent developments in film studies and theories of spectatorship (Barker 2009, Marks 2000, Sobchack 2004). This article builds on some of these ideas and asserts that a focus on the sonic can significantly enrich our understanding of the cinematic experience. In contrast to earlier 'visually orientated' models of spectatorship then, I argue that an exploration of the intersubjective and affective properties of sound opens up the possibility of an ethical spectatorship based on listening.

Apichatpong's films and video work present a rich tapestry of storytelling traditions: folklore, likay folk theatre, soap opera, horror movies, adventure stories and science fiction - all of which have, and continue to play, apart in the formation of the Thai cultural imaginary. These frames of reference are broadened further as his work also demonstrates a number 
of Western influences including American structural and avant-garde filmmaking and European art cinema (Ingawanij and MacDonald 2006). Born in Bangkok in 1970, Apichatpong grew up in the town of Khon Kaen in Northeast Thailand and studied architecture at Khon Kaen University before completing a Masters of Fine Arts at the School of Art Institute in Chicago where he made his first short films in 1994. On returning to Bangkok, he formed the independent production company, Kick the Machine, and made his first feature film, Mysterious Object at Noon (Dogfar nai meu marn, 2000). Since then, he has gone on to make several feature films, shorts and video installations exhibiting his work both nationally and internationally. He has been an active supporter of Thailand's independent film culture, co-directing the fifth Bangkok Experimental Film Festival in 2008. His most recent full-length feature film, Uncle Boonmee Who Can Recall His Past Lives, won the coveted Palme d'Or at Cannes in 2010.

While Apichatpong's work has been the subject of a great deal of critical attention, particularly following the success of Uncle Boonmee Who Can Recall His Past Lives, the importance of sound in his films and his collaborations with sonic artists Akritchalerm Kalayanamitr and Koichi Shimizu have rarely been discussed. ${ }^{1}$ Akritchalerm has been the sound designer on all of Apichatpong's films since Tropical Malady. Born in Bangkok in 1975, he studied Political Science and International Affairs at Thammasat University, before going to study filmmaking in San Francisco where he graduated from film school in 2000. Since returning to Thailand, Akritchalerm has worked on a number of important films including Pen-ek Ratanaruang's Ploy (2007) and Nymph (2009), Aditya Assarat's Wonderful Town (2007), Anocha Suwichakornpong's Mundane History (Jao nok krajok, 2009) and Naomi Kawase's Nanayomachi (2008). He collaborated with Koichi Shimizu on the sound and video installation Anat (t)a (2006-8), which was exhibited in Bangkok and Rotterdam at the $37^{\text {th }}$ International Film Festival. Born in Japan in 1972, Shimizu studied audio engineering in New York from 1991 to 1993 before moving to Bangkok in 2003 where he has worked as a music producer, multimedia artist, and composer for television commercials and films including Pen-ek Ratanaruang's Invisible Waves (2006) and Ploy (2007), and Aditya Assarat's Wonderful Town. Credited alongside Akritchalerm as a sound designer, he also composed the scores for Apichatpong's Syndromes and a Century and Uncle Boonmee Who Can Recall His Past Lives.

Bringing together influences and sources from a wide variety of storytelling traditions, Apichatpong's films blur the boundaries of personal and social memory. Using narrative techniques such as repetition, fragmentation and convergence (as different threads of a narrative resonate uncannily both within and across the films), the work expresses what the process of remembering feels like, how the warp and weft of the past continuously moves through and shapes the present just as the present shapes our memories of the past. Made during a period of continued political unrest in Thailand, in a culture policed by strict lèse majesté censorship laws, the films tend to focus on the experiences and memories of those on
I. A notable exception is May Adadol Ingawanij's conference paper 'Sounds from life and the redemption of experience in Apichatpong Weerasethakul's films', delivered at the Screen Conference, Glasgow, 2008. 
2. See David Teh's 'Itinerant Cinema: The Social Surrealism of Apichatpong Weerasethakul', Third Text, Vol. 25, Issue 5, 20II, 595-609, for a detailed account of the historical and political context that informs Apichatpong's work the social and political periphery, such as characters from Thailand's impoverished northeast, Burmese migrant workers, gay men, older women and children, whose voices are generally absent from public discourse. His more recent work, the Primitive Project, moves towards a more explicitly historical framework as it is concerned with memories of Thailand's violent past that have largely been 'forgotten' in official records ${ }^{2}$.

In film studies, the relationship between memory and representation is most often described in visual terms (the use of certain editing techniques such as the flashback, for example) and yet, the focus on the cinematic image misses the mnemonic potential of the sonic. Like sand disappearing through the hourglass, sound cannot be held still. As Walter Ong describes, 'Sound exists only when it is going out of existence. It is not simply perishable but essentially evanescent, and it is sensed as evanescent' (Ong 2002: 32). The evanescence of sound makes it a rich metaphor through which to explore the transient, and often, involuntary nature of memory. However, the sonic realm also has 'concrete', material properties that affect both the body and the imagination of the listener. As Walter Benjamin describes in 'A Berlin Chronicle':

The déjà vu effect has often been described. But I wonder whether the term is actually well chosen, and whether the metaphor appropriate to the process would not be far better taken from the realm of acoustics. One ought to speak of events that reach us like an echo awakened by a call, a sound that seems to have been heard somewhere in the darkness of a past life ... [T] he shock with which moments enter consciousness as if already lived usually strikes us in the form of a sound. It is a word, tapping, or a rustling that is endowed with the magic power to transport us into the cool tomb of long ago, from the vault of which the present seems to return only as an echo.

(Benjamin 2007: 59)

Benjamin's words make a powerful connection between memory's flow and the affective properties of particular sounds, which act as mnemonic triggers. Through an analysis of the sound design of Apichatpong's films, this article similarly explores the materiality of sound - in particular, its rhythms, tones and timbres - in an attempt to understand, not what these sounds might 'represent', but how the affective power of the sound design might capture a sense of how it feels to remember.

Alongside frequent bursts of exuberant pop music in the films, Akritchalerm uses environmental sounds to create rhythmic 'sonic sequences' that have themselves an almost musical quality reminiscent of experimental avant-garde compositions from the 1950s and 60s made up of single or multi-tracked field recordings such as those by Steve Reich and John Cage. This artistic practice in America was mirrored in Europe by the work of musiqueconcrète pioneer Pierre Schaeffer who made compositions using tape recorders and 'found' sounds, and later in Canada with the introduction of the 'World Soundscape Project' led by R. Murray Schafer. 
Influenced by Husserl, Schaeffer developed a phenomenological approach to sound analysis that was interested in describing the perceptual qualities of a sound rather than attaching it to a source and the information it might convey. As he explains: '[ $t$ ]he dissociation of seeing and hearing ... encourages another way of listening: we listen to the sonorous forms, without any aim other than that of hearing them better, in order to be able to describe them through an analysis of the content of our perceptions' (Schaeffer 2005: 78).

Through this technique, Akritchalerm's soundtracks mediate and transpose the soundscapes of lived space into the cinematic experience, communicating a sense of character interiority and perception through the use of subjective sound and point-of-audition. In combination with the image, the composition of electronic scores and 'found' field recordings foregrounds sound's materialism - its 'concreteness' - and its relationship to touch, sight, and taste. This form of textual synaesthesia encourages a feeling of sensory immersion on the part of the spectator as the senses become indistinct. The perceived permeability of the imaginary boundary between the 'body' of the film and that of the spectator is a common response to Apichatpong's audio-visual aesthetic. As Graiwoot Chulphongsathorn writes of his first experience watching Tropical Malady: 'After the credits had ended, I wanted to embrace the film and slowly melt into it. Momentarily, I did not exist and felt no different from the wind in the middle of the jungle at night' (Chulphongsathorn 2004). Sound theorist Brandon LaBelle claims that listening makes permeable the boundary between self and other partly because of its close relationship to touch and the way its presence is felt on and through the body; according to the laws of physiology, a sound wave only becomes a sound when it reaches and vibrates the bones in the inner ear (Ashmore 2000: 65). It is perhaps this intimate connection of sound to our bodies, I will suggest, that makes it particularly able to create a sense of commonality and sensory exchange in cinema.

The link made by Graiwoot above, between the sound of a film and the spectator's embodied perception of it, has been theorised by Laura U. Marks as 'haptic hearing' (Marks 2000: 183). By foregrounding the 'texture' of sound using techniques such as excessive amplification, vibration or distortion, sound design can communicate 'feeling' through its close association with the sense of touch, and by extension, emotion (Coulthard 2012). Apichatpong's short film Mobile Men (2008) is an example of how haptic sound can be both viscerally and emotionally powerful. Made as part of the 'Art for the World: Stories on Human Rights' project, Apichatpong describes the film as a 'portrait' of Jaii, a migrant worker from Burma. Intended to 'instil and capture his confidence and dignity', the filmmaker gives the hand-held camera over to Jaii and his Thai companion, Nitipong, on the back of a moving truck allowing them to film themselves, and to some extent, take ownership of their own representation (Weerasethakul 2009). As I shall discuss in more detail later, in Apichatpong's work, extended driving sequences like this communicate a feeling of transcendent rapture, a few moments of ecstatic 
transformation where the subjects of the films are given temporary reprieve from the oppressive realities of everyday life. For Apichatpong, the truck in Mobile Men becomes 'a small moving island without frontiers where there is freedom to communicate, to see and to share' (Weerasethakul 2009). As the truck speeds along, the sound of the wind dominates the soundscape as it whips ferociously around the microphone creating an atmosphere of violence and intensifying pressure. Nitipong mutely points to his lips, then to the logo on his chest, the stitching on his jeans and finally down to his trainers where he points at similar details silently gesturing towards the products of a cheap migrant labour force exploited by capitalism. He then stands up, removes his shirt and begins to strike various 'strong-man' poses. Jaii then points to his tattoos (which, he shouts over the wind, were intended to impress girls) and, laughing, tells us that having them done was agony. Jaii rips off the microphone taped to his chest, and attaches it to the tattoo on his upper arm, symbolically connecting voice or perhaps more accurately, voicelessness, with pain. He then throws back his head and lets out a gut-wrenching primal roar that is both a release of tension and a desperate cry of protest that is ultimately lost on the wind.

With haptic sound, Marks explains, 'the aural boundaries between body and world may feel indistinct: the rustle of trees may mingle with the sound of my breathing, or conversely the booming music may inhabit my chest cavity and move my body from the inside' (Marks 2000: 183). In the analysis that follows, I attempt to develop these ideas as I demonstrate how the soundscapes of Apichatpong's films enable a sense of connection and intersubjectivity by appealing directly to the spectator's embodied self. My approach also engages with Felicity Callard and Constantina Papoulis' claim that theories of affect move discussions of memory on from 'an understanding of subjectivity and of experience that is based on an internal world, on particular formulations of memory and representation' towards a concern with the 'nonrepresentational and extralinguisitic aspects of subjective experience' (Callard and Papoulis 2010: 247). Importantly therefore, I will demonstrate how haptic sound also allows us to move away from questions of signification towards a closer understanding of our embodied engagement with the acoustic world.

Drawing very directly on Apichatpong's own memories of love and loss following the death of his father and the break-down of a relationship, and weaving together various forms of popular Thai storytelling traditions, Tropical Malady, like Mysterious Object and Blissfully Yours, foregrounds the memories and experiences of those on Thailand's social and political margins. Filmed on location in Petchaburi and Khao Yai national park, Tropical Malady is made up of two separate but interrelated stories. The first is the portrayal of a romance between Tong, a young male villager, and an army patrol soldier named Keng, set in a bustling small town where they go on dates to the movies, a restaurant, and the market, and spend time together in the countryside around Tong's family home. Arnika Fuhrmann argues that, in contrast to mainstream Thai cinema that tends to represent homosexuality as a form of 'damage' (both socially and individually), the film 'pursues the strategy of re-anchoring homosexuality 
in the mundane, public, and collective aspects of life in Thailand, in an affectively shaped social environment' (Furhmann 2008: 217). In my analysis of the film's sound design, I want to draw out this sense of affect to explore how this 'mundane, public, and collective' space depicted in the film can be understood as political. Foregrounding a sense of intimacy (both through the narrative and through the film's use of sound), the scenes I turn to now share a somatic and emotional appeal that transcends, or perhaps rather circumvents, language - privileging instead, the epistemology of embodied memory.

Tropical Malady begins with a black screen and a distinct hissing sound like static on old film - a juxtaposition that again heightens our awareness of the materiality of the film (made on $35 \mathrm{~mm}$ ) and immediately foregrounds a sense of tactility. Reminiscent of the opening of a silent film, an inter-title reads:

"All of us by our nature are wild beasts. It is our duty as human beings to become like trainers who keep their animals in check and even teach them to perform tasks alien to their bestiality."

Suddenly, with an abrupt cut to a group of soldiers in bright daylight, we see that the men have found the body of a man in the long grass on the outskirts of the jungle and are posing with the corpse for macabre group photographs. Rather than using the convention of an establishing shot, beginning the film in medias res with an unstable, handheld camera momentarily destabilises the objectivity of the spectator's position by creating a rush of sensory stimulation. This effect is heightened by the constant loud 'whssshhh' sound of the wind through the long grass and the men's bodies brushing against it - tactile, 'natural' sounds that form a stark contrast with the high-pitched, 'artificial' electronic beeping from their walkie-talkies and the digital camera against which they are juxtaposed. The soundscape tells us that this is no pastoral idyll.

The kinetic sounds of the men's bodies in this constantly moving environment are captured by the microphone (recorded on location at the time of filming) reaching our ears at what seems to be a slightly exaggerated level. The effect of this is to create a sense of immediacy or 'presentness' by heightening the phenomenological aspects of the scene. This is emphasised further by the close-perspective recording, which captures in rich detail the materiality of the diegetic sounds, such as those that convey the stiff, man-made texture and cumbersome weight of the tarpaulin (used to make a stretcher for the body) as the men drag it through the grass. The use of sound in this very textured way in this opening scene, by focussing on sound's materiality, establishes a pattern that will recur throughout the film in terms of the way it uses sound not simply to convey information, but to give the scene a sense of rhythm, and produce a feeling of intimacy between the film and the spectator. As the film cuts to an extreme long shot of the soldiers walking through the field, the sound of the wind continues to dominate the soundtrack while the 
image works in synchrony to capture the soft, undulating rhythms of the grass as the wind blows over it. Illustrating what Michel Chion terms 'visual microrhythms', which he describes as 'movements on the image's surface ... [which] create rapid and fluid rhythmic values, instilling a vibrating, trembling temporality in the image itself ... [affirming] ... a kind of time property to sound cinema as a recording of the microstructure of the present' (Chion 1994: 17), in this moment, narrative is momentarily suspended, as the aural and visual rhythms of the environment become the focus of attention. Through the synchronicity of sound and image, it is as though time itself has been paused to allow the spectator to contemplate the multiple, vibrating energies of the present moment creating a sense of Bergson's memory-time that draws together the different time frames of perception and recollection in a single instant.

A further layer to the 'texture' of the sound in this opening scene is added as a heavily distorted female voice transmitted through the walkietalkie cuts through the wind: 'Forest fire on M. O. 12. Copy, over'. As one of the soldiers begins to flirt with her across the airwaves, their dialogue mimics a kind of hammy soap opera script, only eerily accented by sonic distortion and static electricity making their voices resonate uncannily around the field:

'Pretty Patcharee all alone. Do you need a friend?'

'I have lots of friends but my heart is still free.' (The soldiers respond humorously with smiles and camp 'oooohs!')

'Then I'll stop by. Don't be a stranger.'

'Is that Sawang? I've only heard your voice. I've never met you in person.'

'I'm at M.O.4. I hope my voice can soothe your heart. Can you sing us a song?'

As the soldiers walk away from a fixed camera towards the jungle, their voices begin to fade, becoming almost indistinguishable from the sound of the wind. Like the characters, the spectator struggles to catch the words:

'What? There's too much static - I can't hear you very well.'

'That's static from my heart. It's calling out to you ... Can I request a song?'

'Your battery might run out. I'll request a song from the radio. Is there a signal out there? ... This is for all you lonely guys. You're hot and wild like a forest fire.'

At this, the compressed sound of a hip-hop drum-fill (the intro of the film's theme song, 'Straight', by Thai band Fashion Show) is heard on the soldiers' radio. The low-angled camera dollies forward through the grass (like a predatory animal silently lurching forward to stalk its prey) and the sound becomes louder, gaining resonance as it shifts from the rather tinny diegetic sound emanating from the onscreen source of the radio to the more expansive, 'full' sound of the same song now heard on the nondiegetic soundtrack. When the soft, male vocals and lush guitar chords of the song's verse come in (echoing the sensuous sonic qualities of the wind 
through the grass), the image cuts to a long shot where the naked figure of a man crosses the frame from left to right, glancing briefly towards the direction of the now static camera. The figure then leaves the frame as the song's middle eight draws into focus an electronic arpeggio of melodic blips and bleeps that echo the soldiers' communication devices. As these sounds merge with the diegetic, ambient sounds of insect life, the screen fades up to a mid shot of Keng looking directly into the camera lens as he watches Tong's mother prepare a meal for her family and his patrol the night he and Tong first meet.

The sound design in the next part of the film imparts a building, pulselike rhythm to a series of scenes shot in the style of observational documentary through the use of location sound recording. Importantly, in these scenes the materiality or 'concreteness' of the setting's quotidian soundscape is foregrounded and environmental sounds are given equal weight to dialogue. As Benedict Anderson has noted, in the first part of the film,

there is no background music at all: instead the sounds of everyday country life, motorbikes, dogs barking, small machines working, and so on. The mostly banal conversations are also essentially background', and one does not need to pay careful attention to their content. Foregrounded are faces, expressions, body-language, silent communication with eyes and smiling lips. The elderly woman whom Tong calls Mae [mum] shows by her expression that she understands the courtship going on, but she says nothing about it, nor does anyone else in the village.

(Anderson 2009: 161)

The soundscape moves from the hum of motorbikes and beeping car horns in the bustling street scenes, to the industrial sounds of percussive hissing and chipping, and the frenzied mechanical whirring of the machinery at the ice factory where Tong works. It then moves to a basketball game where he relaxes with his work-mates, to another noisy street scene, and then back to the factory. Orchestrated by Akritchalerm, this sonic sequence juxtaposes different elements of the ambient soundscape in order to build the rhythm and create an almost musical sense of phrasing that shapes both the mood and tone of the scene. This highly affective, multilayered sound design, incorporating the extremes of environmental sound and street rhythm, articulates a sense of the developing relationship between the two men in place of dialogue.

These sounds and street rhythms reach a crescendo (literally, but also dramatically) in a scene that takes place in the rural outskirts of the town, after Keng has been trying to teach Tong to drive so he can get more work delivering ice. In a sudden heavy downpour, they run for cover underneath a sala (a wooden structure in the forest). Although the volume of the torrential rain on the soundtrack is extremely loud, at first their dialogue is just audible: 'T'm soaked,' Tong says. 'Are you cold?' Keng asks him, before handing him a gift that he has brought him (a copy of a cassette by 
3. While the presence of subtitles for non-Thai speakers complicates this argument, I would maintain that the general feel of the scene in terms of sensory impression remains the same.
Thai pop band, Clash). In turn, Tong passes him a photograph from his wallet of himself when he was a soldier stationed at Kanchanaburi. Keng lies back and says, 'Ah, a soldier has a lonely heart'. Tong adds, 'You never die a natural death', to which Keng replies, 'I'd hate to die without having loved', gazing at the photograph. When Keng asks Tong who the other man is in the photograph, the camera draws back and films the scene in long shot. As the camera's position changes, so too does the point-ofaudition which, in synchrony with the image, retreats to some distance away resulting in the dialogue being almost completely drowned out by the sound of the rain. The withdrawal of the microphone from the intimate space between them creates a narrative ellipsis - we do not find out who the figure was, and perhaps neither does Keng.

As I described at the beginning of this article, the vococentrism of classical cinema requires ambient sound to be lowered in the mix in order to ensure that dialogue remains audible. Although this is just one of many conceits used in film to maintain the illusion of naturalism, it is far removed from the reality of how the acoustic realm is perceived in lived space. By contrast, in this scene, as elsewhere in Apichatpong's work, 'natural' ambient sound appears heightened, to such a degree that the human voice has become inaudible. At this moment in Tropical Malady, while possibly quite authentic to the auditory experience of monsoons in Southeast Asia, to global cinema audiences (particularly in the North and West), the sound of the rain appears so exaggerated that it becomes almost denaturalized, thus heightening the sound's affective power through its disassociation from that which is signified: Schaeffer's 'sonorous forms' (Schaeffer 2005: 78). Rather than relying on language to convey information about the lovers' relationship, the sound design enables an embodied, phenomenological engagement with the sensuality of the scene, communicating 'feeling' trans-diegetically. ${ }^{3}$ As the interplay of sound and image here produces a sense of synaesthesia (the sound and sight of raindrops running off the leaves might evoke the sense of touch for example), at the same time, it also performs a narrative function, expressing the unspoken erotic dimension to Keng and Tong's relationship.

The sense of temporal suspension witnessed at the beginning of Tropical Malady, in the field by the forest, occurs again later on, in a scene that signals the transition between the two parts of the film and similarly depends on affect to communicate aspects of the narrative. Standing in a deserted street at night after their date at the cinema (significantly, beneath Thailand's national flag and a yellow flag with royal or Buddhist insignia), Tong voraciously licks Keng's hand and fingers before disappearing into the darkness leaving Keng standing alone in stunned silence. On the soundtrack, the soft electronic arpeggios from the middle section of the film's theme song are heard again, this time acting as a bridge between the film's two halves as Keng drives through the night on his motorbike back to his base.

As mentioned earlier in relation to Mobile Men, long takes like this from the viewpoint of moving vehicles accompanied by joyous nondiegetic pop music are a recurrent visual and sonic motif in Apichatpong's 
work that convey a floating, dream-like state (Römers 2005). A similar sequence occurs in Apichaptong's previous film Blissfully Yours, a film that also follows a bifurcated structure, divided between urban and rural locations. The earlier film dramatises the experiences of Min, an illegal Burmese immigrant living in the border town of Khon Kaen in northeast Thailand. The first forty-five minutes are set in the stifling atmosphere of the town and feature a series of frustrating encounters in various bureaucratic settings. The second (following a belated credit sequence) takes place in the jungle of the Khao Yai National Park on the ThaiBurmese border. May Adadol Ingawanij and Robert Lowell MacDonald note that the film's opening scenes, in which all three central protagonists lie or evade the truth, portray the town as 'a site of intense alienation' that drives them to make their escape to the jungle in search of a release (Ingawanij and MacDonald 2006: 51). The transition between the urban and the rural takes place during an extended driving sequence through a winding country road and is accompanied on the soundtrack by a soaring, euphoric pop song by Thai singer Nadia that dominates the diegetic sounds of the car's engine and the surrounding environment. The music seems to denote the characters' transition into a state of bliss as they abandon the worries of their everyday lives.

In each of these transitional sequences, the 'dream-state' effect is underscored by the use of sound. Chion explains that 'suspension occurs when a sound naturally expected from a situation ... becomes suppressed, either insidiously or suddenly. This creates an impression of emptiness or mystery, most often without the spectator knowing it; the spectator feels its effect but does not consciously pinpoint its origin' (Chion 1994: 132).

Although noticeably out-of-kilter with the rest of the film, the effect is quite different when this void is filled by non-diegetic sound, as it is in these scenes in Tropical Malady and Blissfully Yours. Carole Piechota has discussed similar occasions in recent American films where a pop song dominates the soundtrack for the duration of the sequence. In these scenes, she contends, the affective power of the music is such that the cinematography becomes subordinate to the rhythm of the song, which momentarily controls the film's temporal register. In these moments, dramatic time is suspended, creating what she calls an 'audiovisual passage'. According to Piechota, these 'passages' elicit an affective response from the spectator where the music is not simply an expression of the protagonists mood or character, but rather seems to transcend the diegetic framework altogether, moving the spectator accordingly. As she argues, 'As these passages frequently last for several minutes (often the length of a pop song) and either lack or downplay dialogue, the perceiver is left with more time to acknowledge or contemplate her bodily and affective experiences' (Piechota 2009 cited in Shaviro 2010: 85).

As he rides through the town, for a minute and a half, the non-diegetic pop song that plays over this scene seems to simulate Keng's state of bliss and suggests that he is oblivious to events going on around him. This oblivion is registered sonically as the music obliterates all diegetic sound. Even as he passes the market place (which we remember from his date 
with Tong earlier as a vibrant, bustling and noisy place), the diegetic sound is completely, and surreally, absent. The song also effaces a temporal elision, providing a non-narrative bridge to the following morning when we see shots of Keng and his troupe being driven to their new placement. This transitional use of sound provides psychological insight as it suggests that Keng is still exhilarated from the previous night's erotic strangeness. Crucially, although this sequence is concerned primarily with feeling and pleasure, it also provides an example of what David Teh has termed the 'camouflage politics' of Apichatpong's work, as it (seemingly almost incidentally) draws attention to the social dissonance and violence that this bliss-state might conceal (Teh 2010). This is seen when Keng passes the marketplace and rides past a group of men brutally kicking a man in the stomach as he lies on the floor. They then run after the bike (where the camera is positioned) hurling bricks at it, apparently unnoticed by Keng.

In the second part of the film, entitled 'The Spirit's Path', the narrative totally abandons the quotidian sociability of the first half as it takes on the form of folklore, drawing on the long traditions of oral storytelling that cross the borders of Thailand, Burma, Laos, and Cambodia. The human voice is almost completely absent in this part of the film, which mostly takes place at night in near total darkness. Describing the difference in tone between the two parts of Tropical Malady, Jihoon Kim writes, "The transposition of everyday life into dreamlike, mystical, and infinite landscapes - a dense forest in Blissfully Yours and an obscure jungle in Tropical Malady - is accentuated by elliptical editing, extremely long takes (with fixed camera or smooth tracking), and the deep ambience of diegetic sound' (Kim 2010: 128). In contrast to the domestic and urban soundscapes of the first part of the film, the 'deep ambience' of the second is achieved through Akritchalerm's combination of field recordings of jungle sounds and electronic effects. The jungle is bursting with sounds of life: animal calls, birdsong and insects buzzing. From somewhere in the darkness, a guttural cry is followed by the regular, rhythmic song of crickets that rises suddenly in pitch as if in response, and merges with the sound of hoarse barking coming from deep within the thick undergrowth. The crickets continue, the varying pace of their rhythm building tension like orchestral stridulation in a horror film: 'a sharp, high, slightly uneven vibrating that both alarms and fascinates' that, like tremolo, 'concentrates our attention. ..making us sensitive to the smallest quivering on the screen' (Chion 1984: 21, 20).

That this rich, affective soundscape draws primarily on field recordings (gathered by Akritchalerm), like the recordings of the jungle in Uncle Boonmee Who Can Recall His Past Lives, demonstrates a strong commitment to acoustic authenticity. Resonating with the film's overarching thematic concern with extinction and preservation, the use of these sounds can perhaps be understood therefore as a kind of 'acoustic archive'. This 'archive' preserves not only the sounds themselves (under threat from deforestation), but also a sense of the long-standing relationship felt between rural northeastern Thais and their auditory environment - what acoustic anthropologist, Steven Feld, has termed 'acoustemology' - a way 
of 'knowing and being in the world' through sound (Feld 2003: 226). In Benedict Anderson's essay on the reception of Tropical Malady in Thailand, he recounts a conversation he had with a friend from the northeast, who explained to him the centrality of sound in the lives of those who live near the jungle where animism is widely practiced. He explains that in the animist tradition, as humans can be reincarnated into animals after their death, the voices of deceased loved ones can be heard in the calls of birds and animals. As he explains, 'an uncle who died recently can be recognized in an owl hooting at night. When they sleep, people's spirits leave the body, and bring back messages [from the dead], sometimes in dreams' (Anderson 2009: 164). Although seeming to incorporate fantastical elements such as spirit guides speaking through animals, these elements and, in particular, the film's 'animist' use of sound, form part of a 'realist' narrative therefore, which is grounded in the regional experience, and understanding, of the acoustic realm. Drawing on the acoustemologies of Thailand's rural northeast, then, the film's sound design, like that of Uncle Boonmee, is able to capture an 'indexical trace' of the spirit world (Ingawanij 2009: 100).

While Tropical Malady deals mainly with personal memory, Apichatpong's fifth feature film, Syndromes and a Century blurs the boundaries of personal and social memories by connecting his family's story with that of a wider socio-political framework. The film is centrally concerned with the preservation of memory following the death of his father, and is based on Apichatpong's recollections of the stories told to him by his parents about their time working as doctors in a hospital before they were married. Their interrelated memories form the film's two halves (firstly from the perspective of a female doctor based on Apichatpong's mother, named Toey, and secondly an army trained doctor based on his father, called Nohng). As such, each half of the film resonates with feint traces and uncanny reflections of its double, as Apichatpong's recollections of his parents' memories form an elliptical and enigmatic narrative involving flashbacks and circular repetitions, formal devices characteristic of memory's representation on film discussed earlier. As Kong Rithdee notes, 'the elusive nature of what is inherited and what is actually remembered constitutes the enigma of Syndromes and a Century, a film in which time is fragmented and memories compartmentalised' (Rithdee 2007).

Like Apichatpong's earlier films, the use of structural bifurcation in Syndromes and a Century brings about a series of 'doubles' that foreground a sense of the fluidity of memory. Jihoon Kim argues that, the parallels and repetitions that occur between the two halves of the film form a cyclical pattern reminiscent of the effect of video looping in multi-screen video art which 'organize[s] the spatial arrangement and distribution of various temporal modalities - simultaneity, ellipsis, comparison, leaps into the future, the disparity between past and present, contestations between different viewpoints on a single event, and so forth' (Kim 2010: 135). Both halves of the film take place in hospitals: firstly, a small country hospital in Khon Kaen; and secondly, a large modern hospital in Bangkok. Hospitals and medical centres are another recurrent trope in Apichatpong's work and 
connote both physical and psychological healing. The English title of the film, Syndromes and a Century, however, extends this theme to a broader socio-historical framework, as Apichatpong's intimate family memories are made to resonate with those of the Thai nation: 'Everyone is a relative', we are told. While the first part of the film is dialogue-led and characterised by natural light, lush green plant life, and the natural, environmental sounds of its rural setting, the second, by contrast, features mostly artificial, fluorescent lighting, significantly less dialogue and a highly affective electro-acoustic score by Koichi Shimizu and Akritchalerm.

In an interview with Kong Rithdee, Apichatpong explains that the sound design for Syndromes and a Century was planned at the time of filming and was intended to communicate with the spectator on a visceral level:

While filming at the hospital, the sound of construction pounded in my heart. Ideas for sound design developed in this way. And during editing, there were sound effects that I wanted to experiment with ... I wanted [the sound to] resonate in the heart. I didn't want it to sound like a score or to have a clear melody, but to blend into the film's ambience. For the viewer to be aware of sound design but not be overly conscious - I tried to tune it to the same frequency as the viewer, to their heartbeat or their blood pumping so the sound is naturally absorbed into their body.

(Weerasethakul 2008)

The notion of synchronicity between the film's score and the body of the spectator that Apichatpong describes here brings into focus ideas about bodily connection and sensory exchange that have been implicit in my analysis of his work thus far. It infers a sense of mutuality (symbolically, a dialogic and discursive space) that draws on the epistemology of embodied memory, a shared sense of how it feels to remember that is grounded in the senses. The insistent materiality of the film score in Syndromes and a Century (reminiscent of musique concrète) connects with, and extends, several of the traits found in the earlier films' sound design with regard to the relationship between sound, perception and phenomenology. The sound design towards the end of Syndromes and a Century becomes even more abstract however as heightened diegetic sounds merge with the electro-acoustic score, drawing out a symbolic connection between 'broken' bodies and a 'broken' state - a connection that has particular significance when considered against the backdrop of the political instability and violence that ensued in Bangkok after the 2006 coup d'etat which unseated Prime Minister Thaksin Shinawatra (Pongsudhirak 2008).

This connection occurs during a long sequence that begins with Nohng meeting a colleague who shows him around the hospital. When they go down the stairs to the basement (a hidden, subterranean space), the doctor explains to Nohng, 'the basement is reserved for military patients, war veterans and their relatives'. 'Everyone is a relative', Nohng answers. 'I know, small country huh?' he laughs. The film cuts to a workshop in one 
of the basement rooms where prosthetic limbs are being made and tried on by amputee patients. The mood changes abruptly as a disk drill whirs maniacally against the oppressive electric hum of the fluorescent strip lights above. A low, non-diegetic electronic drone slowly builds momentum, deepening in resonance as if seeping beneath these diegetic sounds like blood. This malevolent mood is underscored by the sound of rhythmic banging (perhaps of metal on metal) as the camera tracks slowly along the hospital corridor. Composed of multiple layers of industrial and electronic sound, enhanced by the use of reverb and delay, the tone of the soundscape here is both extremely melancholy and, at times, menacing, with the addition of a rhythmic electronic pulse that mimics the sound of a racing heart. With the absence of dialogue in this sequence in Syndromes and a Century, the deep resonance of the score communicates through our bodies a pain occurring on a national level ('everyone is a relative') that is unspeakable within the Thai public domain.

In the final moments of the film however, the unnerving sounds of the basement fade as the melodic voice of a woman singing outside accompanies a visual cut to the lake by the hospital. Nearby some people are waltzing, oblivious to the horror we have just witnessed in the basement. As the camera scans the scene, we see a large crowd doing aerobics to an upbeat pop song (the sound of jouissance in Apichatpong's films) and some monks playing nearby with a toy UFO. That Syndromes and a Century ends in this way, with such a startling contrast between the joyousness 'above ground' and the horror of the basement, complicates any simplistic 'reading' of the film through its sound design. And yet, that this seemingly innocuous moment was one of four scenes in the film that Thailand's Board of Censors demanded were cut is perhaps evidence in itself of a darker element in Thailand's political landscape and the control it has (or attempts to have) over its film culture (Ingawanij 2008). ${ }^{4}$

In Background Noise: Perspectives on Sound Art, Brandon LaBelle contends that " $\mathrm{t}]$ heories of listening are often based on the notion of diffused subjectivity: through listening, an individual is extended beyond the boundaries of singularity ... toward a broader space necessarily multiple' (LaBelle 2006: 245). Through my analysis of the haptic soundscapes of Apichatpong's films, I have shown how the relationship between sound and intersubjectivity that LaBelle describes, can be achieved in film through particular recording techniques and uses of rhythm in the films' scores or diegetic soundscapes, and I have argued that sound design can create a feeling of intimacy and closeness through its appeal to the spectator's embodied self. A theory of spectatorship based on empathy and closeness that also acknowledges alterity marks a significant move away from (ocularcentric) psychoanalytic approaches that have, until recently, dominated film studies (such as found in the work of Jean-Louis Baudry, Christian Metz and Laura Mulvey). Connecting point-of-view with psychoanalytic theory - specifically, Lacan's 'mirror phase' - not only do these approaches seem to focus almost exclusively on the image, they also describe spectatorial engagement largely in negative terms, arguing that
4. The director refused to cut the film and instead, with support from several other key figures in Thailand's independent film scene, organised the 'Free Thai Cinema' campaign with the aim of reducing the state's power to ban and cut films. See Apichatpong Weerasethakul, 'The Folly and Future of Thai Cinema under Military Dictatorship', Thai Film Foundation, 08.1 I.07 http://www.thaifilm.com/ articleDetail_en.asp?id= 106 [accessed 24.01.13] 
this process creates illusions of empowerment (Baudry 1974-75; Metz 1975; Mulvey 1975). Neglecting sound, however, means that they fail to address the many different ways that audiences connect with, and respond to, audio-visual media. Shifting the focus from the image to sound - and in particular to the interplay of sound and image - significantly enriches our understanding of how films make meaning and allows us to consider spectatorship in much more positive, potentially progressive, terms. In contrast to earlier 'visually orientated' models of spectatorship then, I hope to have shown through my analysis of these films how an exploration of the intersubjective and affective properties of film sound opens up the possibility of an ethical spectatorship based on the shared experience of listening.

\section{SOURCES}

Anderson, Benedict (2009), 'The Strange Story of a Strange Beast: Receptions in Thailand of Apichatpong Weerasethakul's Sat Pralat' in James Quandt (ed.), Apichatpong Weerasethakul, Vienna: Austrian Film Museum, pp. 158-177.

Ashmore, Jonathan (2000), 'Hearing' in Patricia Kruth and Henry Stobart? (eds.), Sound, Cambridge: Cambridge University Press, pp. 65-88.

Assarat, Aditya (2007), Wonderful Town, film, Thailand: Pop Pictures.

Barker, Jennifer (2009), The Tactile Eye: Touch and the Cinematic Experience, CA: University of California Press.

Baudry, Jean-Louis (1974-75), 'Ideological Effects of the Basic Cinematic Apparatus', Film Ouarterly, 27:2, pp. 39-47.

Benjamin, Walter (2007), 'A Berlin Chronicle' in Peter Demetz (ed.), Reflections: Essays, Aphorism, Autobiographical Writings, New York: Schocken Books, pp. 3-60.

Callard, Felicity and Constantina Papoulis (2010), 'Affect and Embodiment' in Susannah Radstone? (ed.), Memory: Histories, Theories, Debates, New York: Fordham University Press, pp. 246-262.

Chion, Michel (1994), Audio-Vision: Sound on Screen, translated by Claudia Gorbman, New York: Columbia University Press.

Chulphongsathorn, Graiwoot (2006), 'Monster!: I survive through other people's memories', Criticine, www.criticine.com/feature_article. php?id $=35$, accessed 18.03.08.

Coulthard, Lisa (2012), 'Haptic Aurality: Listening to the Films of Michael Haneke', Film-Philosophy, 16:1, pp. 16-29.

Dyer, Richard (2010), Nino Rota: Music, Film and Feeling, London: BFI \& Palgrave Macmillan.

Feld, Steven (2003), 'A Rainforest Acoustemology' in Michael Bull and Les Back (eds.), The Auditory Culture Reader, Oxford: Berg, pp. 223-239.

Furhmann, Arnika (2008), 'Ghostly Desires: Sexual Subjectivity in Thai Cinema and Politics After 1997', PhD dissertation, University of Chicago, Illinois. 
Ingawanij, May Adadol (2008), 'Disreputable Behaviour: The Hidden Politics of the Thai Film Act', Vertigo 3.8, Summer. http://www. vertigomagazine.co.uk/showarticle.php?sel=bac\&siz=1\&id=927 [accessed 24.01.13]

Ingawanij, May Adadol and Richard, Lowell MacDonald (2006), 'Blissfully whose? Jungle pleasures, ultra-modernist cinema and the cosmopolitan Thai auteur', New Cinemas: Journal of Contemporary Film, 4:1, pp. 37-54.

Ingawanij, May Adadol (2008), 'Sounds from life and the redemption of experience in Apichatpong Weerasethakul's films', conference paper presented at the Screen Conference, 5 July, University of Glasgow.

Ingawanij, May Adadol (2009), 'Observing Life's Remains', 55 Internationale Kurzefilmtage Oberhausen, Festivalkatalog, pp. 99-101. Kawase, Naomi (2008), Nanayomachi, film, Japan and Thailand: JDCT.

Kim, Jihoon (2010), 'Between Auditorium and Gallery: Perception in Apichatpong Weerasethakul's Films and Installations' in Rosalind Galt and Kar Schoonover (eds.), Global Art Cinema: New Theories and Histories Oxford: Oxford University Press, pp. 125-140.

Kongsakul, Sivaroj (2010), Eternity, film, Thailand: Pop Pictures.

LaBelle, Brandon (2006), Background Noise: Perspectives on Sound Art, New York and London: Continuum.

Marks, Laura U. (2000), The Skin of the Film: Intercultural Cinema, Embodiment, and the Senses, Durham and London: Duke University Press.

Metz, Christian (1975), 'The Imaginary Signifier', Screen, 16:2, Summer, pp. 14-76.

Mulvey, Laura (1975), 'Visual Pleasure and Narrative Cinema', Screen, 16:3, Autumn, pp. 6-18.

Ong, Walter J. (2002), Orality and Literacy: The Technologizing of the Word, London and New York: Routledge.

Piechota, Carole (2009), 'Touching Sounds: The Audiovisual Passage in Contemporary Cinema', prospectus for $\mathrm{PhD}$ Dissertation, Wayne State University, Michigan.

Pongsudhirak, Thitinan (2008), 'Thailand Since the Coup', Lournal of Democracy, 19:4, October, pp. 140-153.

Ratanaruang, Pen-ek (2006), Invisible Waves, film, Thailand: Fortissimo Films.

Ratanaruang, Pen-ek (2007), Ploy, film, Thailand: Fortissimo Films.

Ratanaruang, Pen-ek (2009), Nymph, film, Thailand: Fortissimo Films.

Rithdee, Kong (2007), 'Cinema of Impermanence' Criticine, www. criticine.com/review_article.php?id $=24$, accessed 10.3.08.

Römers, Holger (2005), 'Creating His Own Language: An Interview with Apichatpong Weerasethakul', Cineaste, 30:4, Fall, pp. 42-47.

Schaeffer, Pierre (2005), 'Acousmatics' in Christopher Cox and Daniel Warner (eds.), Audio Culture: Readings in Modern Music, New York and London: Continuum, pp. 76-81.

Shaviro, Steven (2010), Post Cinematic Affect, Ropley, UK: Zero Books. 
Sobchack, Vivian (2004), Carnal Thoughts: Embodiment and Moving Image Culture, Berkeley and London: University of California Press.

Suwichakornpong, Anocha (2009), Mundane History, film, Thailand: Electric Eel Films.

Teh, David (2010), 'On Sovereign Framing: Parergon in Southeast Asian Film and Video', conference paper presented at the $6^{\text {th }}$ Association of Southeast Asian Cinemas Conference, Ho Chi Minh City, Vietnam.

Teh, David (2011), 'Itinerant Cinema: The Social Surrealism of Apichatpong Weerasethakul', Third Text, 25:5, pp. 595-609.

Weerasethakul, Apichatpong (2000), Mysterious Object at Noon, film, Thailand: Kick the Machine.

Weerasethakul, Apichatpong (2002), Blissfully Yours, film, Thailand: Anna Sanders Films.

Weerasethakul, Apichatpong (2004), Tropical Malady, film, Thailand: Anna Sanders Films.

Weerasethakul, Apichatpong (2006), Syndromes and A Century, film, Thailand: Anna Sanders Films.

Weerasethakul, Apichatpong (2007), 'The Folly and Future of Thai Cinema under Military Dictatorship', Thai Film Foundation, http:// www.thaifilm.com/articleDetail_en.asp?id=106 [accessed 24.01.13].

Weerasethakul, Apichatpong (2008a), interview with Kong Rithdee, Syndromes and A Century, DVD, BFI.

Weerasethakul, Apichatpong (2008b), Mobile Men, film, Thailand: Dorje Films.

Weerasethakul, Apichatpong (2009), interview with 'Art for the World', http://art-for-the-world.blogspot.com/2009/01/interview-withapichatpong.html, accessed 7.7.10.

Weerasethakul, Apichatpong (2010), Uncle Boonmee Who Can Recall His Past Lives, film, Thailand: Kick the Machine, Illuminations Films and Anna Sanders Films.

Weerasethakul, Apichatpong (2012), Cactus River, film, Thailand: Kick the Machine.

Weerasethakul, Apichatpong (2012b), Ashes, film, Thailand: Mubi.

\section{CONTRIBUTOR'S DETAILS}

\section{Dr Philippa Lovatt, Digital Design Studio, Glasgow School of Art}

Philippa Lovatt is a lecturer in Sound Theory at Glasgow School of Art. She gained her PhD in 2011 from the University of Glasgow. Her thesis 'Cinema's Spectral Sounds: Memory, History and Politics' analysed the use of sound in a group of important films produced in cultures of censorship by Bahman Ghobadi (Iran), Jia Zhangke (China) and Apichatpong Weerasethakul (Thailand). In response to the silencing of unofficial memories in authoritarian regimes, the study explored the politics of voicing and listening, drawing attention to the counter-discursive strategies at work in the films' different uses of sound, and suggested ways that we might think of film as testimony. A monograph based on the thesis 
is currently in development. Philippa is also a freelance film programmer and recently curated a season of Independent Chinese films as part of Takeaway China, an annual festival of Chinese Film and Photography in Glasgow.

Contact: philippalovatt@gmail.com 